\title{
КИСЛОТОНЕЙТРАЛИЗУЮЩАЯ СПОСОБНОСТЬ ПОЧВЕННЫХ ВОД СЕВЕРОТАЕЖНЫХ ЛЕСОВ ПРИ СНИЖЕНИИ АЭРОТЕХНОГЕННОЙ НАГРУЗКИ МЕДНО-НИКЕЛЕВЫМ КОМБИНАТОМ
}

\section{Ершов В.В., Исаева Л.Г., Иванова Е.А.}

Институт проблем промышленной экологии Севера КНЦ РАН, Anamuты, slavo91@gmail.com, isaeva@inep.ksc.ru,ivanova@inep.ksc.ru

Почва является важнейшим компонентом лесных экосистем и служит аккумулятором техногенных соединений элементов, вовлекаемых в биогеохимические циклы. Важной составляющей почвы является вода, заполняющая пространства между твердыми частицами. Химический состав почвенных вод позволяет получить информацию, как о доступности соединений элементов питания, так и о негативном воздействии поллютантов на лесные экосистемы. Важнейшим фактором почвообразования, внутрисистемных биогеохимических циклов и питания растительных сообществ является почвенная кислотность $[4,6]$. Значимый вклад в кислотность почв и почвенных вод вносит древесный опад, который является крупнейшим источником органического вещества и элементов питания почвы [3]. Воздушное промышленное загрязнения является крупномасштабным фактором, оказывающим негативное воздействие на лесные экосистемы в зоне воздействия предприятий АО «Кольская ГМК». Загрязняющие вещества вызывают повреждения ассимилирующего аппарата хвойных древесных растений и дефолиацию деревьев не только в фенологические сроки, что содействует увеличению количества опада $[2,3,7]$ и, соответственно, изменению кислотности почв и почвенных вод. Биохимический состав исходного растительного материала и характер опада (свежий, гумифицированный) заметно влияют на качественный состав мобильных соединений почвенного гумуса, присутствующих в почвенных водах. Повышению кислотности почвенных вод способствуют кислотные дожди, формирующиеся в результате выбросов в атмосферу соединений серы и других кислотообразующих агентов. Важнейшей почвенно-химической характеристикой является кислотно-основная буферность почвы, которую определяют, как способность почвы противостоять изменению рН при добавлении к почве кислоты или основания. Так как значения рН почвы измеряются в водной фазе, буферность экспериментально характеризуют как способность жидкой фазы почвы, находящейся в равновесии (или в контакте) с твердой фазой, противостоять изменению $\mathrm{pH}$. В мировой литературе при оценке буферности почв к кислотам широко используются понятие и термин «кислотонейтрализующая способность (ANC) почвы» [5].

Цель данного исследования - оценить кислотонейтрализующую способность почвенных вод северотаженых лесов при снижении аэротехногенного загрязнения с учетом меж - и внутрибиогеоценотического варьирования.

\section{объекты и методы исследования}

Объектами исследования послужили почвенные воды в ельниках кустарничковозеленомошных и сосняках кустарничково-лишайниковых на разных стадиях дигрессии.

Почвы на объектах исследования представлены Al-Fe-гумусовыми подзолами. Отбор проб почвенных вод выполнен на мониторинговой сети площадок ИППЭС КНЦ РАН. Пробные площади (ПП) находятся на разном удалении от источника загрязнения - комбината «Североникель»: 7-10 км - стадии соснового и елового техногенного редколесья, 28-31 км - дефолиирующие леса и более 100 км - фоновая территория. Каждая ПП оснащена лизиметрами гравитационного типа (12 шт. на ПП) расположенными на разной глубине в соответствии с генетическими горизонтами почв (А0, Е, $\mathrm{Bhfa}, \mathrm{BC} / \mathrm{C}$ ) и с учетом микромозаичной структуры биогеоценоза (под кронами и между крон) [3]. Образцы вод фильтровались через бумажный фильтр «синяя лента». Металлы определяли методом атомно-абсорбционной спектрофотометрии, анионы (нитраты и сульфаты) - методом ионообменной хроматографии. Для оценки способности почвенных вод к нейтрализации кислоты использовали показатель кислотонейтрализующей способности (ANC), рассчитываемый в мг-экв/л как разность между суммой доминирующих катионов $\left(\mathrm{Ca}^{2+}+\mathrm{Mg}^{2+}+\mathrm{K}^{+}+\mathrm{Na}^{+}+\mathrm{NH}_{4}^{+}\right)$и суммой анионов ми- 
неральных кислот $\left(\mathrm{SO}_{4}^{2-}+\mathrm{Cl}^{-}+\mathrm{NO}_{3}^{-}\right)$[8]. Согласно отчетности по площадке Мончегорск $\mathrm{AO}$ «Кольская ГМК» за 2012 г., компания в течение 8 лет соблюдает норматив предельно допустимых выбросов. Это способствовало снижению выбросов сульфатов по площадке Мончегорск за период 1990-2014 гг.: $\mathrm{SO}_{2}$ (тыс.т/год) - с 232.5 до 33.5 (в 6.9 раза) (данные АО «Кольская ГМК»). Статистическая обработка данных проводилась с использованием программ Statistica 10 (анализ МаннаУитни) и MS Excel (описательная статистика).

\section{Результаты исследования}

На фоновой территории показатель АNC в водах из всех горизонтов почв в подкроновых и межкроновых пространствах в еловых и сосновых лесах уменьшается с глубиной и имеет положительное значение (таблица 1), за исключением почвенных вод из ВС горизонтов в межкроновых пространствах еловых лесов. Снижение показателя ANC с глубиной можно наблюдать в еловых и сосновых лесах в подкроновых и межкроновых пространствах, что связано со снижением концентраций низкомолекулярных алифатических органических кислот [1]. В еловых и сосновых лесах показатель ANC в водах подкроновых пространств достоверно выше ( $<<0.05)$, чем в межкроновых пространствах, исключение составляют почвенные воды из ВС горизонтов - значения показателя здесь достоверно не различимы.

Таблица 1. Значения показателя ANC (мг-экв/л) в почвенных водах еловых и сосновых лесов.

\begin{tabular}{|c|c|c|c|c|c|}
\hline \multirow{2}{*}{$\begin{array}{c}\text { Тип } \\
\text { состояния }\end{array}$} & \multirow[t]{2}{*}{ Глубина } & $\begin{array}{c}\text { Еловые } \\
\text { леса }\end{array}$ & $\begin{array}{c}\text { Сосновые } \\
\text { леса }\end{array}$ & $\begin{array}{c}\text { Еловые } \\
\text { леса }\end{array}$ & $\begin{array}{c}\text { Сосновые } \\
\text { леса }\end{array}$ \\
\hline & & \multicolumn{2}{|c|}{ Под кронами деревьев } & \multicolumn{2}{|c|}{ Между крон деревьев } \\
\hline \multirow{6}{*}{ Фон } & \multirow{2}{*}{ A0 } & $0.68 *$ & 0.80 & 0.24 & 0.45 \\
\hline & & $0.05 * *$ & 0.06 & 0.02 & 0.04 \\
\hline & \multirow{2}{*}{$\mathrm{E}+\mathrm{B}$} & 0.26 & 0.39 & 0.14 & 0.25 \\
\hline & & 0.04 & 0.02 & 0.02 & 0.02 \\
\hline & \multirow{2}{*}{$\mathrm{BC}$} & 0.14 & 0.13 & -0.001 & 0.15 \\
\hline & & 0.03 & 0.02 & 0.02 & 0.02 \\
\hline \multirow{6}{*}{$\begin{array}{l}\text { Стадия } \\
\text { затухающей } \\
\text { дефолиации }\end{array}$} & \multirow{2}{*}{ A0 } & 0.03 & 0.30 & 0.35 & 0.21 \\
\hline & & 0.03 & 0.02 & 0.02 & 0.01 \\
\hline & \multirow{2}{*}{$\mathrm{E}+\mathrm{B}$} & -0.09 & 0.04 & 0.07 & 0.02 \\
\hline & & 0.03 & 0.02 & 0.01 & 0.01 \\
\hline & \multirow{2}{*}{$\mathrm{BC}$} & -0.06 & 0.05 & 0.01 & 0.03 \\
\hline & & 0.01 & 0.02 & 0.01 & 0.01 \\
\hline \multirow{6}{*}{ Редколесье } & \multirow{2}{*}{ A0 } & -0.15 & 0.07 & -0.03 & 0.01 \\
\hline & & 0.02 & 0.03 & 0.01 & 0.02 \\
\hline & \multirow{2}{*}{$\mathrm{E}+\mathrm{B}$} & -0.08 & -0.07 & -0.07 & 0.02 \\
\hline & & 0.02 & 0.02 & 0.01 & 0.01 \\
\hline & \multirow{2}{*}{$\mathrm{BC}$} & -0.07 & 0.004 & -0.07 & \\
\hline & & 0.02 & 0.01 & 0.02 & \\
\hline
\end{tabular}

Примечание: *-среднее значение, **-стандартная ошибка

Различия в значениях показателя ANC между фоновой территорией и дефолиирующими лесами - достоверны $(\mathrm{p}<0.05)$, за исключением почвенных вод из ВС горизонтов еловых лесов в межкроновых пространствах. В почвенных водах дефолиирующих еловых и сосновых лесов значение показателя ANC ниже, чем на фоновой территории, за исключением вод из $\mathrm{E}+\mathrm{B}$ в межкроновых пространствах еловых лесов и вод из Е+В горизонтов в подкроновых пространствах сосновых лесов (здесь различия не достоверны). 
В дефолиирующих лесах показатель ANC в водах из минеральных горизонтов в межкроновых пространствах еловых лесов достоверно выше, чем в подкроновых пространствах. Это может быть обусловлено интенсивным потоком кислотооборазующих веществ с осадками под кронами, а также увеличением количества растительного опада, вызванного дефолиацией хвойных деревьев. Показатель ANC имеет отрицательное значение только в еловых лесах под кронами деревьев в водах из минеральных горизонтов почв.

В еловом и сосновом техногенном редколесье значение показателя кислотонейтрализуещей способности в почвенных водах из всех горизонтов почв подкроновых и межкроновых пространств ниже, чем на фоновой территории. При увеличении техногенной нагрузки на еловые и сосновые леса происходит нивелирование внутрибиогеоценотических различий в показателе ANC.

Показатель ANC имеет отрицательное значение в еловых лесах в подкроновых и межкроновых пространствах и в сосновых лесах в подкроновых пространствах в водах из Е+В горизонтов. Снижение показателя ANC в дефолиирующих и техногенных лесах связано, со снижением концентраций низкомолекулярных алифатических кислот и увеличением концентраций анионов минеральных кислот.

\section{Заключение}

В результате проведенных исследований установлена значительная внутри- и межбиогеоценотическая вариабельность показателя кислотонейтрализующей способности почвенных вод в ельниках и сосняках на разных стадиях техногенной дигрессии. При увеличении техногенной нагрузки на еловые и сосновые леса происходит снижение показателя ANC в дефолиирующих лесах и техногенных редколесьях, и нивелирование внутрибиогеоценотических различий в показателе ANC.

Исследование проводилось при частичной финансовой поддержке РФФИ (грант № 18-35-00170 мол_а).

\section{Литература}

1. Артемкина Н.А, Горбачева Т.Т., Лукина Н.В. Низкомалекулярные органические кислоты в почвенных водах лесов Кольского полуострова // Лесоведение. 2008. № 6. С. 37-44.

2. Иванова Е.А., Лукина Н.В. Варьирование массы и фракционного состава древесного опада сосняков кустарничково-лишайниковых при аэротехногенном загрязнении // Лесоведение. 2017. № 5. С. 47-58.

3. Лукина Н.В., Никонов В.В. Биогеохимические циклы в лесах Севера в условиях аэротехногенного загрязнения. Ч. 1. Апатиты: Изд-во КНЦ РАН. 1996. 216 с.

4. Орлов Д.С. Химия почв. М.: Изд-во МГУ. 1985. 376 с.

5. Соколов Т.А., Толпешта И.И., Трофимов С.Я. Почвенная кислотность. Кислотно-основная буферность почв. Соединения алюминия в твердой фазе почвы и в почвенном растворе. Изд. 2-е, испр. и доп. Тула: Гриф и К. 2012. 124 с.

6. Сухарева Т.А. Пространственно-временная изменчивость кислотности почв северотаежных лесов при снижении техногенной нагрузки // Вест. Мурманского государственного технического университета, 2018. № 21. С. (в печати).

7. Ярмишко В.Т., Лянгузова И.В. Многолетняя динамика параметров и состояния хвои Pinus sylvestris в условиях аэротехногенного загрязнения на Европейском Севере // Изв. С.-Петерб. лесотехн. акад. 2013. Вып. 203. С. 30-46.

8. Van Breemen N., Driscoll C. T., Mulder J. Acid deposition and internal proton sources in acidification of soils and waters // Nature. 1984. V. 307. P. 599-604. 